Diego Gómez-Venegas

Doctoral researcher

Humboldt-Universität zu Berlin

diego.gomezvenegas@hu-berlin.de

\title{
Whose virus - whose code
}

\begin{abstract}
This essay attempts to trace the currents of anxieties and fears that overflowed the digital during the early stages of the Covid-19 pandemic. Traveling with such flows, this work aims to model the questions that, circulating silently in a sort of latent state before the catastrophe, now haunt us as brutally unveiled; namely, to which extent the digital mediations we have attached to ourselves, to our lives, in order to know and experience this world under a protected mode, now push us to witness that that world has expelled us? To which extent these digital mediations tell us that now we belong more to them, than to that old world of which we became blind almost a century ago? Through a post-hermeneutical approach, one that analyzes some of the digital traces left by the rise of this pandemic by discussing them through the lens of media history and media theory, this work seeks to sketch a short media history of loss; the loss of many, the loss of our-selves.
\end{abstract}

\section{Keywords :}

Covid-19, digital mediations, media history, anxiety, loss, post-humanities. 
For Elia

The global outbreak and spread of the virus causing the Covid-19 illness in early 2020 seems to meet all the requirements to constitute an, equally global, cognitive cataclysm. Humanists, or rather post-humanists, seem to be well aware of that. Thus, in the middle of this surge, philosopher Timothy Morton wrote in a social network that "viruses turned out to be kindly, wise elephantine creatures, whose communications took the form of time loops" (Morton 2020), accompanying the text with an image taken from Denis Villeneuve's film, Arrival. There, Amy Adams's character, Louise Banks, is a linguist who faces the unprecedented challenge - after being recruited by a government that by then has already taken the (uni)form of the armed forces - of deciphering the modes of communication of newly arrived extraterrestrial agents that, apparently, have a message to share with the human kind (Arrival 2016). Hence, we see that what Morton is suggesting to us is that this virus, the SARS-CoV-2, has arrived, or rather emerged, to spread something else than only an illness, and that what actually underlies the global crisis is the challenge of facing that, beneath all this frenzy, there is a message that must be decoded.

However, while the virus struck Europe and its long, never ending political debates concerning when and how alien subjects, those 
persistent others, should be allowed to penetrate the limits drawing its old broad silhouette, in March, philosopher of technology Yuk Hui shared, in this case, a distressed online outcry. He reminded us all, in the face of the increasing fears demanding to close every boundary, every door, perhaps even any possibility of encountering a troubling gaze, how not only such fears but perhaps that very silhouette, had been built upon the, until then, still silent murmurs of a political philosophy of immunology. The virus seemed to show "that borders rule", said Hui, recalling that not too long ago, a philosopher who was once concerned with human parks, had openly criticized a European political leader's refugee policy by arguing that "we haven't learned to praise borders." Hui's outcry found thus its final breath: "A curse, poverty of philosophy," he closed (Hui 2020). But, in the very same online thread - whereas reinvigorated nation states along Europe, and all around the world setup emergency policies to close their borders to any other - Benjamin Bratton replied to Hui by succinctly saying: "But they are the wrong borders - they are mostly in the wrong place" (Bratton 2020).

What these online exchanges seem to show - in these strange screen-based times where, literally embracing our electronic devices, we expect that a sudden reflection can show us our own face back - is that at the bottom of our anxieties and fears, an 
already old set of questions still remains: Is our face still there? On which side of the reflection our existence is actually taking place? Can we still keep claiming that we inhabit the real world, and that we possess a sovereign right over it? This pandemic, the most technologically mediated one ever, that which has kept us locked-down watching TV, holding a phone in our agitated hands, has had the power to remind us that, perhaps, we humans "did not survive the death of God by a single minute" (Kittler 1997, 131). This pandemic - the one that has made us seen how a teardrop on a bright screen augments the symbols of that message informing us that a life we knew has vanished - pushes us to ask about the meaning of life and death in a world whose time and void, as Louise Banks was able to decode, we are not yet able to know (Arrival 2016). Hence, this text is an attempt to, coping with our anxieties, fears, and sadness, try to understand how these messages, in-forming us, as erasing "a face drawn in sand" (Foucault 2002, 422), can help us, at the edge of history, to know better who we are.

\section{Symbolic purgatory}

The scientific community seems to agree. Just as these convoluted times are showing, the fast spread of the virus through the real physical world, is followed by enormous flows of initially impenetrable data stored in servers through out the Internet. On March 12, 2020, for example, the Microbiology Resource 
Announcements journal published in its Website an article stating that the whole genome sequence of the SARS-CoV-2 had been isolated in Nepal (Sah et al 2020a). Subsequently, that genetic code was deposited in the gene bank of the National Center for Biotechnology Information (Sah et al 2020b). To somebody without a proper training in microbiology or genetics, these massive and strange amounts of information seem to have emerged, just as the virus, only to slap our understanding. Six columns of ten characters each, four hundred and ninety-six rows all the way down, two thousand seven hundred and sixty-one characters in total, but only four letters: $g, c, a$, and $t$ - a codification obtained after the real RNA thread of the virus is processed by an algorithmic sequencing machine (Illumina 2020), and thus transcribed into the yet ungraspable symbolic deepness of a DNA sequence (Fig. 1). All these sets of data, the codes they harbor, even while they move along with the emergency through out the electronic networks in which we place our hopes and anxieties, can only be traced, however, in layers whose distances would be, apparently away from us, in the profundities of those still too cryptic symbols. 


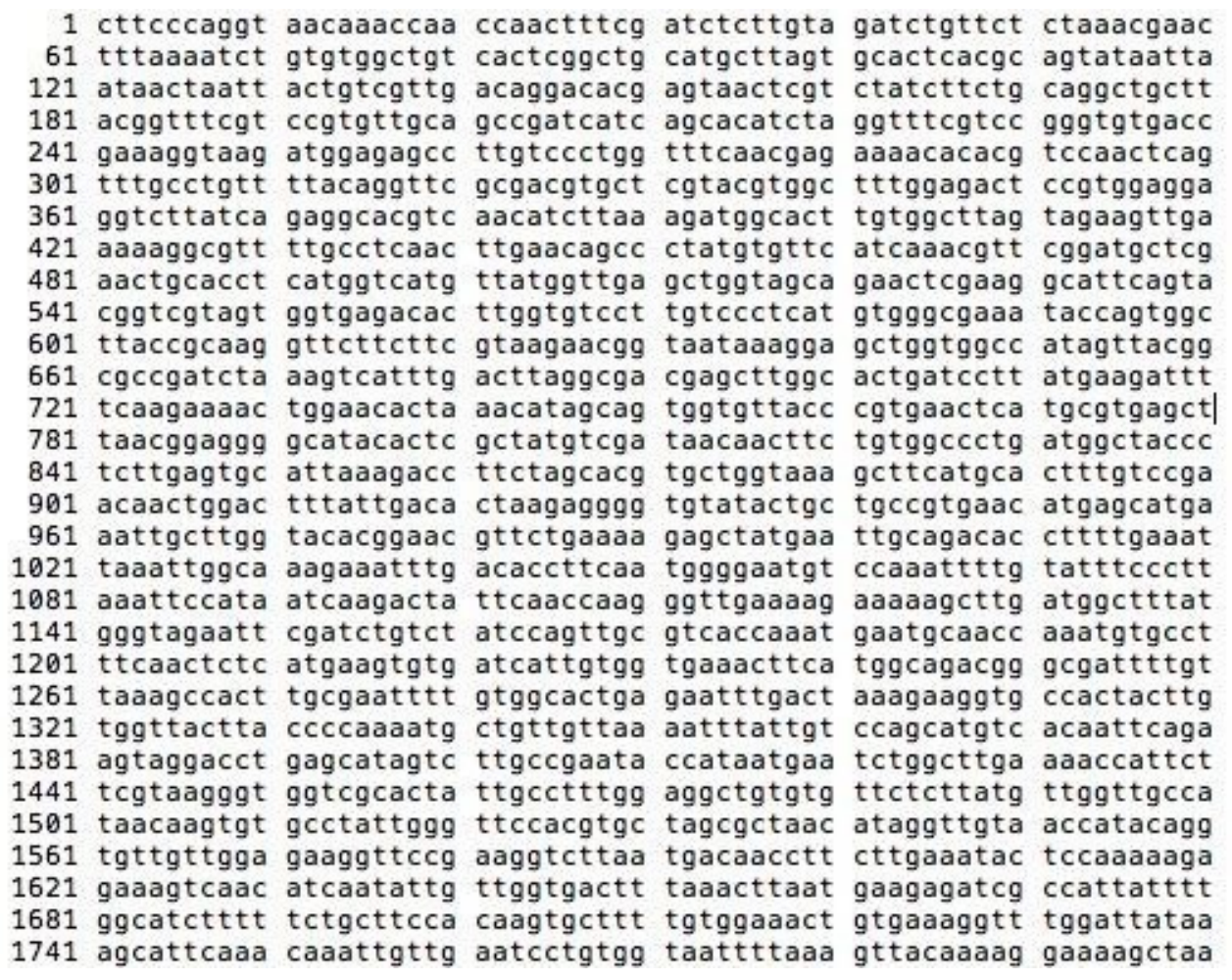

Fig. 1: Nepal's SARS-CoV-2 gene sequence (Excerpt). Ranjit Sah et al. "Severe acute respiratory syndrome coronavirus 2 isolate SARSOCoV-2/61-TW/human/2020/ NPL, complete genome." NCBI. https://wWw.ncbi.nlm.nih.gov/nuccore/MT072688.

On March 15, 2020, The New Yorker magazine used its Twitter account to resurrect from its archive a 1997's article called The Deadliest Virus Ever Known (McDowel 1997). As ironic and surprising as it might be, that report begins by unfolding a now two-decades-old forensic strategy: a young scientist travels all the way from Canada to a remote Norwegian island in the Arctic Circle called Longyearbyen, hoping to dig through the permafrost to exhume seven corpses lying in an old cemetery since 1918. In the late 1990s, medical geographer and climatologist Kirsty 
Duncan - nowadays a politician and former minister of science and sport at Justin Trudeau's government - led an expedition aiming to find traces, still alive in those dead supposedly frozen bodies, of another virus: the so-called Spanish flu - a pandemic that one hundred years ago caused the death of tens of millions all over the world, due to the first known surge of the h1n1 influenza virus. And given that humans learned to cope with viruses by decoding their genetic structures, finding a living sample of the most deadly one seemed not only a reasonable but an urgent task. Put differently, below the invisible cloth of perplexity that now falls over every city and town, over the uninterrupted gazes trapped in bright screens, an old, deep, and extensive enterprise that has taken whole scientific careers, that has involved long geographical expeditions, as well as excavations of dirt and mummified tissue, and which today relies on the surveillance of the entire world, has sought to find, for many years, the next code that would not fit the records in our archives.

We are also told, however, that the invisible presence of viruses is part of the world we inhabit, that they actively and naturally coexist beyond our sight among other species, and that any spread towards our zone responds, at the end, to the modes in which we interact with those others. But still, even then, these modes of interaction are thought insofar as coded communication processes: 
as the New Yorker's article reminds us, the Spanish flu virus seemed to have come from birds, from wild migrant ducks probably, but given that humans theoretically would not have had the cell receptors to directly receive an avian $\mathrm{flu}$, the hypothesis was, already in the late 20th century, that an intermediary channel should have been needed. Thus, a flying duck sends its virus genetic information in the form of falling feces, which in turn arrive at a swine farm. Then the virus is received by a pig, in whose body, altered by this mammal's own genetic code and viruses, it could have been properly glitched for now being transmitted to humans. But that would not have been enough. As with rolling dices, a game of probabilities should have taken place, too: for a killer virus being configured, when duck viruses fall from the sky, a pig must be already infected with a human virus, and thus, only by exchanging codes and producing glitches within the intermediary agent, the hybrid mortal one emerges (McDowel 1997) - information source, transmitter, a channel with noise, receiver, destination, and above all, entropy (Shannon and Weaver 1998, 33-53).

What sort of symbolic purgatory is this? Where are we, really?

The very same year the New Yorker's story came out, John Johnston published the English translation of a then eight years old essay written by Friedrich Kittler: The World of the Symbolic - A World 
of the Machines (Kittler 1997). There, the German theoretician, in the wake of Jacques Lacan, stated that after the death of God had been declared - as it was pointed out above -, human life and its consciousness remained "only the imaginary interior view of media standards" (Kittler 1997, 132). Thus, even in a thought experiment where all human life is wiped out, something still remains; and according to Kittler that is non-human aesthetics (Kittler 1997, 130-131). This is so, because before and after us, signals and codes will keep circulating in the real, and all the more, because now, perhaps more brutally than ever, we humans are trapped deep inside those codes, because the only way we have to perceive and know, is them, the symbolic (Kittler 1997, 135). That is the reason why, in this bio-informatic post-apocalyptic scenario, a machine called Illumina MiSeq and its Burrows-Wheeler Aligner MEM algorithm (Sah et al 2020a) becomes as relevant an agent as the virus itself. It is within them and with them that all incumbent contemporary aesthetics takes place; it is there that the virus genetic constitution is reversely transcribed into a DNA code that, subsequently, could become, although still technologically, intelligible for human knowledge. It is the light of these sort of machines what becomes illuminating.

If we humans are still alive, we are so insofar as we are entrenched, ironically enough, in nonsensical codes. As Kittler once pointed out (Kittler 1997, 140-141), while in the middle 
point of the 20th century psychoanalysis kept trying to make sense of the human mind, it did so by acknowledging that this was only possible by assuming that, as with Claude Shannon's $n$-grams (Shannon and Weaver 1998, 39-44), our understanding surrenders itself to the government of meaningless series; whether these are of the "DAB EE A BEBE DEED DED" kind (Shannon and Weaver 1998, 42 ) or of the "cttcccaggt aacaaaccaa ccaactttcg atctcttgta" type (Sah et al 2020b).

\section{Those others}

Wild (flying) creatures, viruses, codes, algorithmic machines, statistics. This is the cluster of agents ruling our brutal present.

The avian, as it has been said above, seemed to constitute the critical link in the genealogical chain of code exchanges that left humans, realization notwithstanding, at the mercy of viruses during the last one hundred years. Domestic poultry draws one of these strands. In May 1997 physicians in Hong Kong detected the case of a boy infected with a virus so far never seen in humans: h5n1 - a pure, not mixed, avian flu that killed the boy in a matter of days. Researchers found that the boy interacted with chickens at his preschool, but that none of his classmates, nor his family, got infected (McDowel 1997). Could this case mean that mutating within fowl, a new virus, one which human receptors 
were sensible to, had emerged? (McDowel 1997). Or alternatively, could such mutation have taken place in the receiver instead? What sort of probability game would be required for this to happen?

According to Donna Haraway, "[t]o be one is always to become with many" (Haraway 2008, 4). Or in other words, we humans - just as all the species that surround us, which most of the time we don't (want to) see - have become what we are, and what we will be, by going through a "sim-bio-genesis" (Haraway 2008, 31) - not exactly autopoiesis, "but rather [a] reciprocal induction within and between always-in-process critters" (Haraway 2008, 31). From the beginning, our cells would have been filled with genetic information from bacteria, fungi, and protists (Haraway 2008, 3), and moreover, our constant interaction with other species would only keep the exchange going. Thus chickens, one of the primal labor companions to humans, should be, at last, understood as the five-thousand-years-old media apparatus for bio-cultural diversity and exchange they are (Haraway 2008, 266). We humans have become with them for too long, and therefore it is not hard to think, to speculate at least, that through millennia, the avian has somehow become, at some glitched info-genetic level, part of our current self, too. Their presence is massive both in historical and spatial terms. We have forced them to feed us, and we have learned not to care. But then, (im)probably, somebody 
cares and touches, perhaps a little boy in a preschool, and we humans and they avians interact, and exchanges take place. And ironically enough, when nobody cares, when nobody is supposed to care, the probabilities of exchange are only increased; by technically setting the protocols of distance and avoidance, of (un)proper waste management, the avian, inevitably, comes back for us (Haraway 2008, 267-268). The exchange must be completed, the dice is always rolling, and we are part of the game.

But sad faithful chickens cannot fly away. And thus, millions were culled in 2004 when, faster than the spread of viruses itself, fear for a global pandemic emerged due to the detection of a deadly virus infecting humans in or nearby industrial massively packed chicken farms in Asia: again, the h5n1 found years before in Hong Kong (Haraway 2008, 268-269).

However, we humans keep interacting with those others, and some are, still, wild flying creatures - sometimes not even avians, but mammals. On March 17, 2020, Nature published in its Website an article offering clues on where a probable origin of the SARSCoV-2 virus could be found (Andersen et al 2020). And again, this seemed to be a matter of code. Just as it happened with previous viruses outbreaks, the hypothesis of the scientists began assuming that the source of this new case could be related to animal-human exchanges. All the more, given that many of the 
initial cases of infection were reported to be linked to a food market in Wuhan, China, the scientists also assumed that - just as it happened with the SARS-CoV-1 virus in the early 2000 s this could eventually be related to bats. But given that, as this and any other paper would show, what actually takes place in the real of nature can only be assumed, they resorted to the symbolic space granted by databases and archives in order to proceed with the comparative analyses of genetic codes. Thus, they studied a sequenced sample of the RaTG13 bat virus from a gene bank, which effectively showed to be " 96\% identical" to the, also stored in data banks, SARS-CoV-2 virus sequenced genome. However, their code analysis also showed that a portion of the RaTG13 virus' genetic code "may not bind efficiently to [the] human ACE2" receptor, which, as previous analyses of the SARS-CoV-2 code had demonstrated, is the cell receptor through which this novel virus connects to us (Andersen et al 2020). Therefore, another assumption from the real was needed, and in this case implied to think of mammals whose singularity did not rely on wings. Then pangolins were brought into the exchange game. It turns that they are illegally imported and eventually sell in some Chinese food markets, and, of course more importantly for us post-humans, that an available already sequenced genetic code of a corona virus obtained from one of these critters, did match important elements linked to the transmission of the SARS-CoV-2 to humans (Andersen et al 2020). Therefore, the scientists came up with two main 
hypothesis to understand how the virus would have reached its current status: first, the one suggesting that its code could have mutated within one of these animal agents, for which the agent in question should have inhabited an environment with a "high population density" in order "to allow [a process of] natural selection" within the agent's species; and second, the one saying that after "zoonotic transfer", that is to say, interspecies exchange, an still harmless virus in humans was transferred enough times in a highly populated environment, as to adapt itself to its new host's system (Andersen et al 2020).

In other words, what these scientist are showing to us, is that this whole event seems to amount to a matter of transmission, processing, and storage (Kittler 1997, 135) of an x-virus's code - the genealogical ancestor or progenitor of SARS-CoV-2 - between three possible agents - bats, pangolins, and humans -, and that the required changes in that $x$-virus's code to reach its current configuration, could obey to the entropy - the degree of complexity of the probabilities - present in the possible exchanges between the agents involved. Hence, this code examination, as well as the study of its probabilities of exchange and transformation, that is to say, the endeavor that can provide clues about its evolution from the past towards the future, has rested, and it will keep doing so, upon "computational analyses" (Andersen et al 2020). This is, of 
course, also a pure archaeo-genealogical enterprise, where the word origin must recover its historical proximity to the term principle and its double meaning: on the one hand, as the source from where something begins, and on the other, as the foundations and laws through which that something operates (Ernst 2013). Thus, as this scientific approach to virus research exemplifies, our too contemporary humanity approaches that far and always ungraspable real, which we can here call biodiversity or just nature, through algorithmic encoding and decoding technologies, always in search for those still elusive principles - through machines.

Therefore, as many knots of the web sustaining our current existence and our unsettled gazes already show, the symbolic character of the orderings ruling this all too contemporary jargon seem to transcend old fashioned scientific labs. Hence, on March 16, 2020, the data-technologies enthusiasts driven Website called Towards Data Science, published a short report asking if machine learning could be used to predict the possible future mutations of the SARS-CoV-2 virus (Ye 2020). There, a young author, who is of course also a programmer, argues that what really matters in these turbulent times, in this encrypted world - despite the so-called meaning not-so-young readers may be looking for -, is to understand that any existence on Earth depends on codes, and processes of encoding and decoding (Ye 
2020). Be it RNA or DNA, their translation, transcription, and even their mutation, all that amounts, ultimately, to the importance of data, and the informational value that from them can be extracted. All the more, our author knows that no reading is neither needed, but only automated analysis: he asserts that $k$-means algorithms, "a method in machine learning to find groups of data points," can be used in order to parse the data that populating and moving through servers and archives, as it has been pointed out above - will show how mutations are actually behaving, and, accordingly, will offer "insights on the nature of the mutations and how to address them" (Ye 2020). We shouldn't be surprised, then, that our young author had already dissolved his condition as such, by being one of the developers of a technology that, consequently, keeps opening that old void separating authorship from writing (Critiq 2020) - old fashioned readers, deprived of ghostly spirits, are thus left adrift.

In each sentence that you pronounce - and very precisely in the one that you are busy writing at this moment, you who have been so intent, for so many pages, on answering a question in which you felt yourself personally concerned and who are going to sign this text with your name - in every sentence [there] reigns the nameless law, the blank indifference: 'What matter who is speaking; someone has said: what matter who is speaking.' (Foucault 1991, 72) 


\section{State of Exceptional(ien)ism}

On March 12, 2020, the Finish scholar Jussi Parikka used his Twitter account to post a meme split in three acts. First, we had the Simpsons' school-kids enthusiastically asking "Say the line, Giorgio!", for then, in the second act, having a ceremoniously serious portrait of the Italian philosopher with the caption "State of Exception". Of course, in the meme's third frame we saw the Simpsons' young characters with their arms up and their mouths open, rejoiced for having listened what they needed to hear (Parikka 2020). Parikka's tweet had no additional words, and thus, one can assume he shared the image understanding that, somehow, it was the reflection of the moment we were then living. With him, we can also understand that, despite postmodern fables tend to be staged in imaginary cartoonish towns in the USA, old short-tempered European philosophers still seem to know how old immunological European politics operates. Suddenly, Europe's long and sad March saw how, between TV broadcasted death tolls and leaders' speeches, the EU decided to close not only its outer border, but its inner theoretically non-existent ones, too. And thus, as the aged export it is, April and May saw how this apparatus operated in the Americas as well. Asia had done it, as usual, earlier. We persistently, however, kept our sighs attached to those screens that still reflect our ghostly images. As Mark Fisher, a younger and more melancholic (and then still) European philosopher once put it, we seemed to be in a live transmission 
of a tale of death blowing the silent "suspicion that the end has already come, the thought that it could well be the case that the future harbors only reiteration and re-permutation [...] the 'weak messianic' hope that there must be something new on the way lapses into the morose conviction that nothing new can ever happen" (Fisher 2009, 3). But again, that was still ghostly philosophy; the paradoxical reiteration that any end or beginning depends on the exceptional border drawn by our own reflection. Nevertheless, if there is something new this pandemic has brought, are the facts - the data and the codes - demonstrating, once more, that no policy, no politics, and no philosophy should keep being developed upon mirages. "These are the contagions and infections that wound the primary narcissism of those who still dream of human exceptionalism" (Haraway 2008, 32).

What not many 20th century philosophers were willing to acknowledge - although some did -, is that the only permanent state of exception is that imaginary one governing our interior self. The borders that separate us from the world we inhabit, are always there. Thus, perhaps in that search, Benjamin Bratton argued - in a tweet mentioned earlier - against all the borders this virus-reinvigorated real politics aimed to reinstall. "[T]hey are the wrong borders", he said (Bratton 2020). Consistently enough, in a brief and older essay entitled Notes on Extinction, Emergence and Biochemical Design, Bratton alleged 
that the only destiny the human kind can embrace, is that of becoming (with) others; that the only certainty we can have about what will happen after this epoch closes its cycles - and it is difficult not to see this pandemic as part of that closing -, is that what will emerge "is an era in which humans are no longer the dominant geological actor" (Bratton 2014). Thus, following a path similar to the one drawn by Haraway, but in much more cynical or rather melancholic manner - these are indeed the days to embrace melancholy, too -, Bratton insists on that, in other words, we must welcome extinction. He recalls that most of our genes are already non-human, and that our biological constitution is, perhaps always was, a collaborative project with other species shaping us from within (Bratton 2014). In a way, his invitation to embrace extinction is, then, one to finally acknowledge the end of the human as the - always imaginary central figure of the Earth, recalling that beyond this planet, only "a low percentage of all Earthlings in space have been humans," and that despite old fashioned borders, despite old dreams of abandoning this planet to build another Earth, perhaps, despite all, "we [will] survive by perforating the boundaries between animal, vegetable and mineral" (Bratton 2014).

These notes seem to forget, however, that all the possible ways, not only to embrace but to understand such road towards extinction, imply to acknowledge the prior and already ongoing 
process which couples and thus imbricates the human and the machines. It is true that the SARS-CoV-2 virus has been a great reminder to attest that "[w]e have never been human" (Haraway $2008,1)$, and that our genetic composition is full of foreign DNA information; but this pandemic doesn't seem to have asserted with enough clarity that all we may have learned about this ontological multiplicity, about this multi-species DNA mixture, has been possible, in turn, only through a material network of technologies and protocols which, with algorithmic procedures and machines, illuminate us. In this techno-biological apocalypse we tend to give such techno for granted. And just as Bratton mentions the animal, the vegetable, and the mineral while he reminds that other non-human Earthlings has traveled beyond our atmosphere, we, again, tend to forget that the light of machines has not only showed us the coded structure of our own organism, but, with Curiosity or Rosetta, has also showed us the universe. With astonishment we saw, in April 2019, the first image of a black hole; and again, we humans preferred to forget that what we actually saw were four peta-bytes of data, which after being captured by a global network of radio-telescopes, had been processed and encoded by a supercomputer (Max-Planck-Gesellschaft 2019). Thus, just as it happens today in every corner of this planet, we decided then to remain - witnessing our ghostly shadows on the screen - attached to our old friend representation. Even now - among the sighs seeking to blow our 
anxieties away, between screens - we seem to have forgotten that the episteme governing us, is no longer representation, but simulation; not anymore a mere illusion, but the technological simulation that keeps us believing that every image reflects only, with no alien interference, our spirit.

\section{Inconclusive decoding}

Since March 2020, Germany's news-media resurrected the term Geisterspiel - literally, ghost game - to signal the mode through which the national football league would operate due to the measures and restrictions implemented to contain the spread of the SARS-CoV-2 virus: the games would be played with no audience at the stadiums. And even though the matches would be still televised, southern Germany's cultural radio station, SWR2, ironized by adding the caption "Nicht die Seele des Fußballs" not the football's soul, not the football's spirit - (SWR2 2020). It is interesting how ancient rites, as gatherings in coliseums, still project the apparent immutability of certain old beliefs, where ghosts, spirits, and images have had, since times immemorial, a central place. Thus, in August 2019, after second division football club Union-Berlin got its promotion to Germany's top league for the first time since its foundation, thrilled fans took photo-portraits of their dead relatives to the stadium - again, the deep question of the soul - (Süddeutsche Zeitung 2019). Trivial as they may seem, these events exemplify 
how it has been through images, through the deep epistemological thread of representation, that we humans have learned to cope with the always elusive, ghostly space that separates human life from soul, and from death. What are we then? An impenetrable mix of alien DNA code, or the always representable image of a soul? In a way, these seem to be the sort of questions haunting many during these long and lonely pandemic nights in front of glossy mirror-like screens.

Dealing with this problem decades ago, a German scholar once proposed to expel the spirit from those still ghostly sciences that were then the humanities - Austreibung des Geistes aus den Geisteswissenschaften - (Kittler 1980, 7-13). It was the beginning of a project - perhaps the escalation of a previous one - that had declared that the ancient belief stating that the primal source of all meaning was the spirit conforming the interior of all human beings - whose mode of externalization were a series of representation techniques, and whose study was in charge of the sciences of the spirit, as the humanities used to be then called in Germany -, had finally fallen off the cliff; a collapse through which the very notion of the human had been erased, in turn, from any surface, "like a face drawn in sand at the edge of the sea" (Foucault 2002, 422). It was understood, thus, that human beings were no other thing that mere recipients for systems of symbols that had their own secret rules, their own 
inner orderings, and that we were, then, condemned to accept our meaningless inner void to be filled and thus governed by those systems (Kittler 1997). Thus, the subsequent project of the posthumanities, and that of at least one branch of media theory, seem to have taken the challenge of facing extinction precisely from such a void; all the more since it has been concluded that those systems of symbols circulate and propagate, accelerated, due to the rise of the machines (Kittler 1997). Expanding the triad of animal, vegetable, and mineral, have we reached a stage of individuation in which we are destined to become always erasable nodes of a bio-informatic network of exchange? (Galloway and Thacker 2007, 70-77). Beyond the screens, among elusive reflections, these sad pandemic times seem to be, I think, the global cognitive cataclysm through which we finally confront the old dissolution of our souls to accept our fate as instantiations of always circulating codes - mutating or not.

When I started working on this text in mid March 2020 - when fear covered the region from where I write, just as now hits the land where I was born -, I thought of closing it with a conjecture: that in the future a day would arrive in which we will not rely on images of any soul in order to confront death or the void. Instead, I thought, a mode will be discerned to walk that path through code. In early June 2020, the German federal government released the so-called Corona-Warn-App; a smartphone application 
aiming to "quickly disrupt chains of infections" of the SARSCoV-2 virus among human subjects (The Federal Government 2020). To do that, the app makes a cellphone to share random encrypted codes with any other cell-phone with the app it encounters while the user walks through a city or town. These incoming codes are then stored for two weeks in the host device - the average incubation time of the virus -, for then being automatically erased. If a person reports, through the app, that has tested positive for SARS-CoV-2, all the phones storing codes that had come from that person's device, are warned that they have been exposed to the virus (Robert Koch Institut 2020). In other words, since June 2020, at least in this corner of the planet - a planet that clearly doesn't belong to us -, humans have found themselves imbricated, not literally but still materially and symbolically, not only as subjects but as nodes, in a bio-informatic network of data exchanges (Galloway and Thacker 2007). Thus, the last frontier we should cross, the last border we should end removing, is the one that beyond our sight, time ago already, pushed the reason of our existence towards a topology governed by viruses that act as codes, and by codes that act as viruses; always, through machines. 


\section{References}

Andersen, K. G. et al (2020). "The proximal origin of SARSCoV-2", Nature Medicine 26, (2020) [Online]. Available at: https://doi.org/10.1038/s41591-020-0820-9 (Accessed: 29 March 2020)

Arrival (2016). Directed by Denis Villeneuve [Film]. Los Angeles: Paramount Pictures.

Bratton, B. (2020) 18 March. Available at https://twitter.com/ bratton/status/1240122134455779328 (Accessed: 18 March 2020)

Bratton, B. (2014) "Notes on Extinction, Emergence and Biochemical Design." Extinct.ly [Online]. Available at: http://extinct.ly/texts/\#bratton (Accessed: 9 April 2020).

Critiq (2020). Critiq [Online]. Available at: https:// www.critiq.tech/ (Accessed 27 June 2020)

Ernst, W. (2013) "Media Archaeology as a Transatlantic Bridge" in Ernst, W. and Parikka, J. (ed). Digital Memory and the Archive. Minneapolis: University of Minnesota Press, pp. $23-31$.

Fisher, M. (2009). "Its easier to imagine the end of the world that the end of capitalism" in Fisher M. Capitalist Realism. Is there no alternative? London: Zero Books, pp. 1-11.

Foucault, M. (2002). The Order of Things. An Archaeology of the Human Sciences. London: Routledge Classics. Foucault, M. (1991). "Politics and the study of discourse" in Burchell, G., Gordon, G. and Miller P. (eds.) The Foucault 
Effect. Studies in governmentality. Chicago: University of Chicago Press, pp. 53-72.

Galloway, A. R. and Thacker E. (2007). The Exploit. A Theory of Networks. Minneapolis: Minnesota University Press.

Haraway, D. (2008). When Species Meet. Minneapolis: University of Minnesota Press.

Hui, Y. (2020) 18 March. Available at https://twitter.com/ digital objects/status/1240091835768270848 (Accessed: 18 March 2020)

Illumina (2020), "MiSeq System | Focused Power for targeted gene and small genome sequencing" [Online]. Available at: https:// emea.illumina.com/systems/sequencing-platforms/miseq.html (Accessed 22 March 2020) Kittler, F. (1997). "The World of the Symbolic - A World of the Machine” in Johnston, J. (ed.) Literature, Media, Information Systems. Amsterdam: OPA Amsterdam B.V., pp. 130-146. Kittler, F. (1980). Austreibung des Geistes aus den Geisteswissenschaften. Paderborn: Schöningh. Max-Planck-Gesellschaft (2019). First-ever image of a black hole [Online]. Available at: https://www.mpg.de/13337404/firstever-picture-of-black-hole (Accessed: 28 June 2020) McDowel, M. (1997). "The Deadliest Virus Ever Known", The New Yorker, September 1997 [Online]. Available at: https:// www.newyorker.com/magazine/1997/09/29/the-dead-zone. (Accessed: 20 March 2020) 
Morton, T. (2020) 11 March. Available at https://twitter.com/ the eco thought/status/1237744456352305157 (Accessed: 11 March 2020)

Parikka, J. (2020) 12 March. Available at https://twitter.com/ juspar/status/1238195119846801414 (Accessed: 12 March 2020)

Robert Koch Institut (2020). Infektionsketten digital unterbrechen mit der Corona-Warn-App [Online]. Available at: https://www.rki.de/DE/Content/InfAZ/N/Neuartiges Coronavirus/ WarnApp/Warn App.html (Accessed: 28 June 2020)

Sah, R. et al (2020a). "Complete Genome Sequence of a 2019 Novel Coronavirus (SARS-CoV-2) Strain Isolated in Nepal”, Microbiology Resource Announcements, 9 (11 2020) [Online]. Available at: https://doi.org/10.1128/MRA.00169-20 (Accessed: 17 March 2020)

Sah, R. et al (2020b). "Severe acute respiratory syndrome coronavirus 2 isolate SARSOCoV-2/61-TW/human/2020/NPL, complete genome”, NCBI [Online]. Available at: https:// www.ncbi.nlm.nih.gov/nuccore/MT072688 (Accessed: 17 March 2020)

Shannon, C. E. and Weaver, W. (1998[1949]). The Mathematical Theory of Communication. Chicago: University of Illinois Press.

Süddeutsche Zeitung (2019). "Union Berlin ehrt tote Fans bei Bundesliga-Auftakt”, Süddeutsche Zeitung [Online]. Available at: https://www.sueddeutsche.de/sport/fussball-berlin-union- 
berlin-ehrt-tote-fans-bei-bundesliga-auftakt-dpa.urn-newsmldpa-com-20090101-190725-99-204535 (Accessed: 27 June 2020)

SWR2 (2020). "Bundesliga-Geisterspiele: 'Nicht die Seele des Fußballs"”, SWR2 [Online]. Available at: https://WwW.swr.de/ swr2/leben-und-gesellschaft/bundesliga-geisterspiele-nichtdie-seele-des-fussballs-100.html (Accessed: 27 June 2020) The Federal Government (2020). "Coronavirus warning app", The Federal Government. [Online]. Available at: https:// www.bundesregierung.de/breg-de/themen/corona-warn-app/coronawarn-app-englisch (Accessed 28 June 2020)

Ye, Andre. "Machine Learning for Biology: How Will COVID-19 Mutate Next?", Towards Data Science [Online]. Available at: https://towardsdatascience.com/machine-learning-for-biologyhow-will-covid-19-mutate-next-4df93cfaf544 (Accessed: 28 March 2020) 